\title{
MINERALOGICAL AND GEOCHEMICAL INVESTIGATIONS ON FINNISH LAKE ORES ${ }^{1)}$
}

\author{
PETER HALBACH
}

\begin{abstract}
HALBACH, PETER 1975: Mineralogical and geochemical investigations on Finnish lake ores. Bull. Geol. Soc. Finland 48, 33-42.

The limnic ferromanganese ore concretions in some Finnish lakes are described. Their chemical and mineral compositions have been measured as have their natural surroundings - the latter by means of physico-chemical in-situ analysis. The sources of the nodules' contents are discussed, and a theory based on the calculated precipitation fields of the important ore minerals is presented for the ore formation.

Peter Halbach, Mineralogisch-petrographisches Institut, Techn. Universität Clausthal, 3392 Clausthal-Zellerfeld, Bundesrepublik Deutschland.
\end{abstract}

\section{Introduction}

Several lakes in Central Finland have deposits of iron- and manganese-bearing concretions with up to $23 \%$ manganese or $46 \%$ iron (Aarnio 1915). These freshwater ferromanganese nodules occur in the interface of sediment and bottom water or in the upper $\mathrm{cm}$ of the lake sediments. The smaller nodules are like little pellets or flat pastils. The latter are the so-called penny ores. The larger ones are plane incrustations like pancakes, which can be as much as $12 \mathrm{~cm}$ thick, but which average between 4 and $6 \mathrm{~cm}$.

These lake deposits have no interest for economic exploitation of iron or manganese (Vaasjoki 1956). But since deep-sea man-

1 Publication of a lecture at the Geological Society of Finland on the 4th of April 1974. ganese nodules in the Pacific and Indian Oceans are considered as very important future metal resources, abundant mineralogical and geochemical investigations are being made to solve the problem of their origin. The lake ore concretions are similar in several ways to marine manganese nodules. In fact, freshwater nodules and shallow-water marine ferromanganese nodules hardly differ in shape, composition and accumulation rate. The main differences between them and the deep-sea nodules are the faster rate of formation and the lower trace element content of freshwater (Halbach 1974) and shallow-water marine concretions. Most of the factors influencing the origin of the concretions in a lacustrine environment can be observed or measured. Therefore it is important to study the mineralogy, geochemistry and origin of 
freshwater ores in comparison with marine nodules.

Hydroxides and oxyhydrates of iron and manganese in a sedimentary environment generally occur as concretions with more or less concentric zonal structures. The solution, mobility and precipitation of these elements are controlled by oxidation - reduction potential (Eh), concentration of hydrogen ions $(\mathrm{pH})$ and other dissolved components, and by temperature and pressure. Under surface conditions and at a constant temperature $\left(25^{\circ} \mathrm{C}\right)$ the stability of the various phases in aqueous solution can be calculated by the Nernst equation (Berner 1971). An important characteristic of both elements is their ability to form colloidal solutions after precipitation. These pseudosolutions are alternately stable and unstable as a result of interaction with the environment. The incrustation phases were formed by sol-gel transformation, dehydration and ageing and have a final composition of crystalline matter. Therefore both marine and freshwater nodules are characteristically laminated.

\section{Mobilization and migration conditions}

In northern latitudes large-scale dissolution and migration processes of iron and manganese in a terrestrial environment have led to the formation of lake ore deposits stimulated by high humidity and welldeveloped bogs. The conditions for the formation of lake ores were provided by the terrestrial development of swamps after the great ice age, which is why their occurrence in North Europe is limited to the Holocene period.

Bogs or bog water are physico-chemically characterized by the following features:

1. A very low content of electrolytes. Raised bogs tend to have less than $0.3 \% \mathrm{Ca}$ in the dried organic matter.

2. The decomposition of plant material leads to over-production of carbon dioxide and a decrease of $\mathrm{pH}$, hence at a depth of $60 \mathrm{~cm}$ in marshy soils we find 1.0 to $3.7 \%$ $\mathrm{CO}_{2}$. The pH-values in low bogs are between 5 and 6 , and in raised bogs between 3.5 and 5.0.

3. Reducing organic substances released in the bog waters cause low or negative redox potentials, which implies a consumption of oxygen. The redox potentials can be as high as $-100 \mathrm{mV}$.

4. Swamp waters have a high content of humus, which gives the water brown to yellowish-brown colour.

Although iron and manganese are generally included in the weakly migrating elements of the weathering circle, the forementioned conditions provide the best possibilities for the mobilization of both elements. The reducing and acid environment, the lack of oxygen and dissolved carbon dioxide content enables the waters to dissolve iron and manganese out of the rock minerals and to move the divalent ions in bicarbonate solutions (Borchert 1952). The iron (II)- and manganese (II)-compounds are stable in aqueous solution as long as the oxygen content remains $50 \%$ below saturation, the redox-potential is low and the $\mathrm{pH}$-value does not exceed 7.5. But $\mathrm{Mn}^{2+}$-ions in aqueous solution are more stable because the oxidation of $\mathrm{Fe}^{2+}$ to $\mathrm{Fe}^{3+}$ occurs at lower redoxpotentials than that of $\mathrm{Mn}^{2+}$ to $\mathrm{Mn}^{4+}$. This leads to the separation of manganese from iron (Krauskopf 1957), that can be observed in the alternating chemical composition of the concentric layers. Electron microprobe analyses show that the banding consists of alternate zones of Fe-rich, Mn-poor material and Fe-poor, Mn-rich material (Halbach 1972).

Another reason why iron and manganese are mobile in swamp waters is that both elements are able to migrate in organic bond and in colloidal pseudosolutions. The abun- 


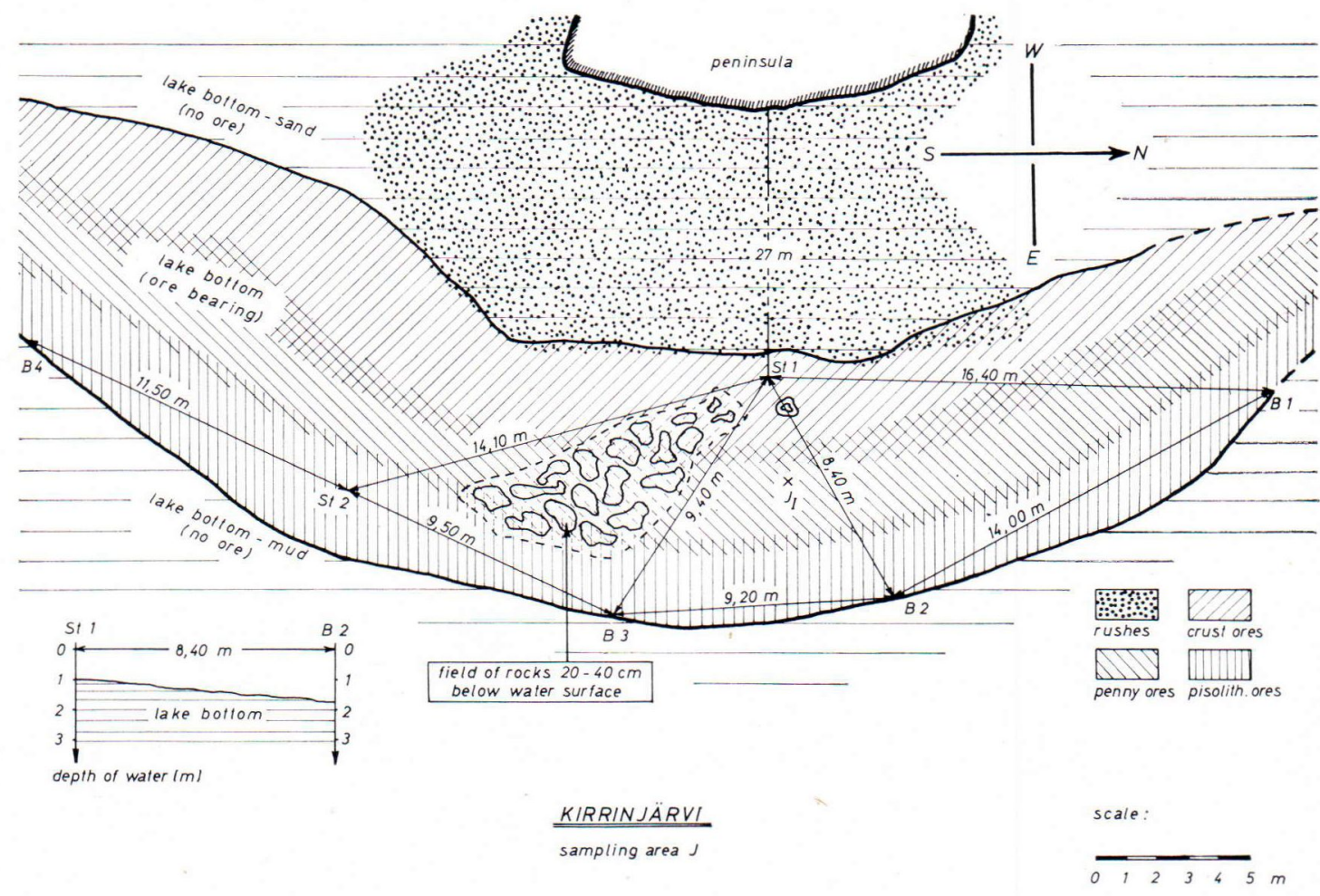

Fig. 1. Map of the western shore of the lake Kirrinjärvi with lake ore distribution

dant humic and fulvic acids enter into complex compounds with heavy metal ions like iron or manganese and prevent their precipitation (Vasari et al. 1972). Furthermore, iron and manganese can be adsorbed by particles of humic matter. Such bound metal ions can be delivered only after the sedimentation of organic matter. They can pass into the interstitial water of the bottom sediments in a dissolved ionic state under reducing conditions.

\section{Occurrence and shapes of lake ore nodules}

The lakes investigated are all located in Central Finland, in regions where the cover of bogs is at least $40 \%$. The lakes are: Salahmijärvi and Rotimojärvi (north-west of
Iisalmi), Paloisjärvi (near Iisalmi) and Kirrinjärvi (west of Jyväskylä).

In some cases the bog areas border immediately on lakes, but usually the colloidal and detrital particles or the dissolved ions enter the lakes by brooks or with the groundwater. In a drainage brook near the lake Kirrinjärvi abundant reddish-brown precipitates of iron hydroxide as products of microbiological activity were visible. The iron oxidizing bacterium leptothrix ochracea ${ }^{1}$ is known to exist here, but this species was not observed in the lake ore concretions. In some samples of manganese-rich nodules we could observe microbial structures resembling me-

1 The bacteria species were determined by Dr. H. Hanert, Botanisches Institut, Techn. Universität Braunschweig (BRD). 


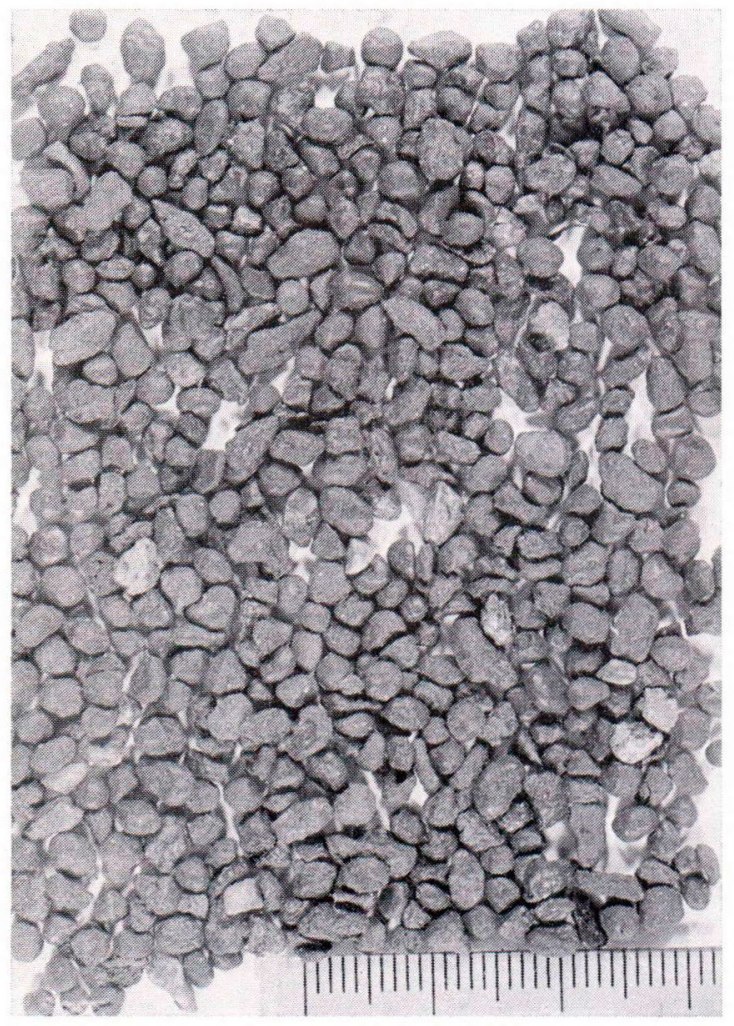

Fig. 2. Placer sample of pisolithic lake ores from Rotimojärvi (scale in $\mathrm{cm}-\mathrm{mm}$ ).

tallogenium ${ }^{1}$ as described by C.A. Dubina (1970). It is to be assumed that this bacterium has a part to play in the precipitation and settling of manganese.

Most of the lake ore fields investigated were in depths of water between 1 and $3 \mathrm{~m}$. They tend to form irregular patches or longish areas lying approximately parallel to the shoreline. The ore content ranges from several $\mathrm{kg}$ to a maximum of about $35 \mathrm{~kg} / \mathrm{m}^{2}$.

Figure 1 is a map of the western shore of Kirrinjärvi showing the lake ore distribution at the bottom of this area. The bottom sediments in the ore field are greenish-brown in colour (similar to fine detritus gyttja), rich in organic matter and with a content of some diatoms. The sediments between the ore

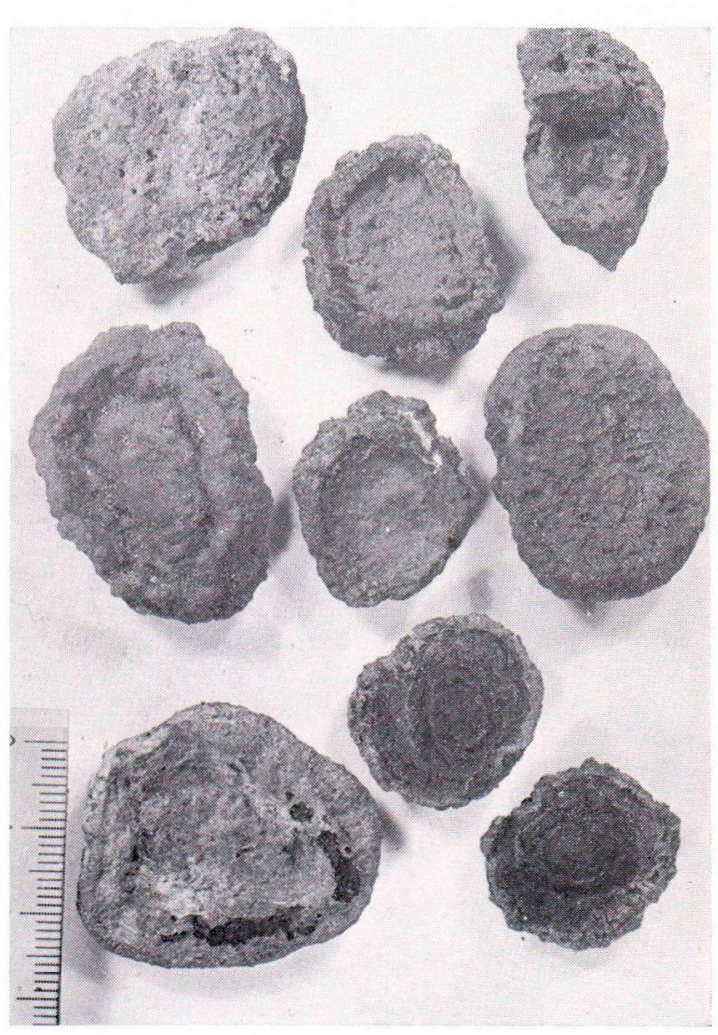

Fig. 3. Penny ores (scale in $\mathrm{cm}-\mathrm{mm}$ ).

field and the shore are more sandy and coarse grained.

The ore field consists of three facies areas with different ore types:

1. pisolithic lake ores in the deepest part of the region,

2. penny ores in the middle part and

3. crust ores in the upper part of the ore field.

This classification into three ore types is valid not only for Kirrinjärvi but also for most of the other lake ore deposits observed.

The pisolithic ores are spherical or pear shaped (Fig. 2) and vary in diameter from several $\mathrm{mm}$ to $1.6 \mathrm{~cm}$. Sometimes the big ore grains exhibit small flattened shapes 


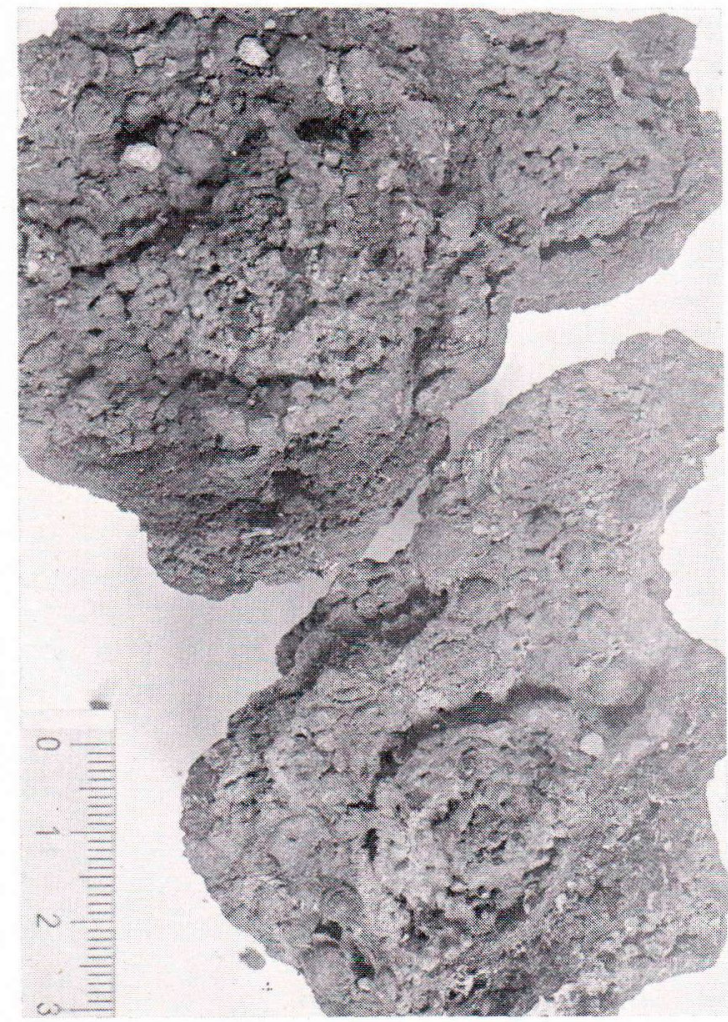

Fig. 4. Discoid nodules of crust ore (scale in $\mathrm{cm}-\mathrm{mm})$.

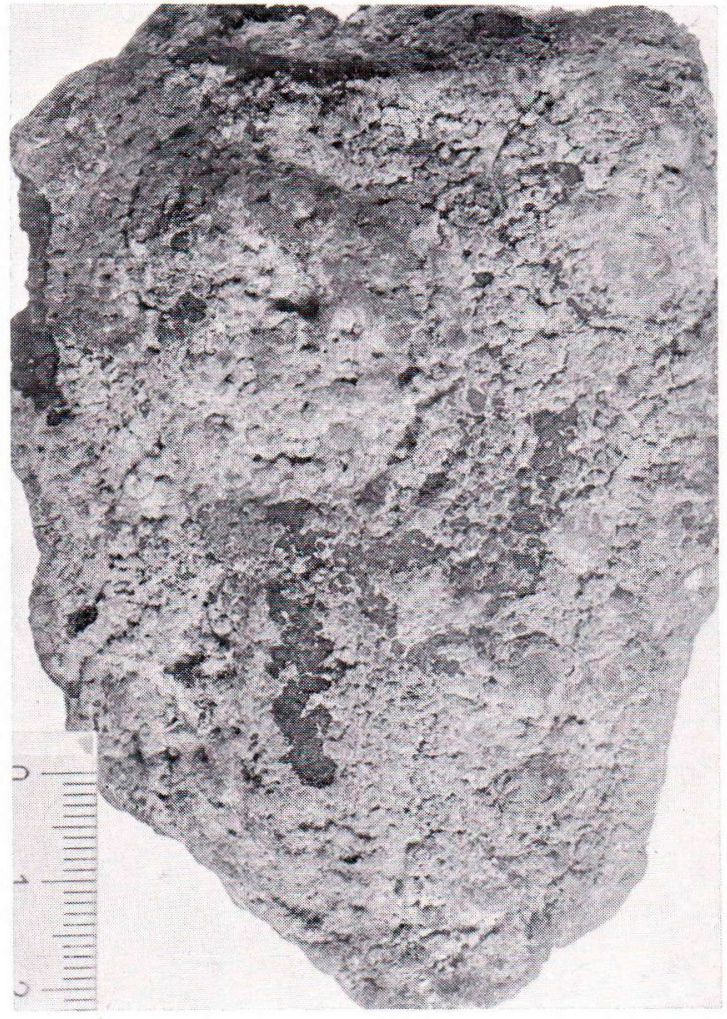

Fig. 5. Flattened crust ore (scale in $\mathrm{cm}-\mathrm{mm}$ ). transitional to the penny ores. This ore type is found on the lake bottom and within the upper $10 \mathrm{~cm}$ of the sediments, whereas the other freshwater ore types are only found on the sediments. Therefore the pisolithic ores can be observed in the areas of the other ore types, too, but only in the underlying muddy sediments.

In some lakes, e.g. in Salahmi- and Rotimojärvi, ore concentrations have been observed in the shore area. These ore grains (Fig. 2) are on a placer deposit and represent pisolithic ores transported by the action of moving water.

The penny ores consist of flattened discoid forms (Fig. 3). In many samples the margin of the single ore pieces tilts upwards forming a basin-shaped figure. The surface is granulous and often includes a nucleus of detrital grains or rock fragments. Concentric ridges on the flat sides of the discs indicate periodic or seasonal agglomeration growth. The thickness of the penny ores is 0.4 to $1.5 \mathrm{~cm}$ and the diameters are about 1.5 to $6.0 \mathrm{~cm}$.

The crust ores sometimes consist of larger, saucershaped nodules (Fig. 4), but the majority are flattened and usually intergrown incrustations several $\mathrm{cm}$ thick (Fig. 5). The significant features of concretions that grew as a result of the agglomeration of colloidal hydrated particles are particularly marked in these nodules.

The accumulation fabrics of the lake ores 
indicate an upward migration of the dissolved substances in the sediment-water interface. Likewise the occurrence of pisolithic ores in the bottom muds is caused by the different solution and oxidation behaviour of iron and manganese. The freshwater ores also display stratifications of iron-rich and manganeserich layers due to the changing of redoxpotentials in the bottom zone.

There are two processes that may be responsible for the transport of the chemical compounds:

1. An active upward movement of interstitial water caused by the diagenetic compacting of the bottom sediment or by the hydrostatic pressure of the local groundwater level.

2. A strong concentration gradient of the dissolved ions in the interface between the interstitial water and the bottom water resulting in an upward diffusion-transport of ions.

\section{Physico-chemical measurements}

Some measurements were made in the ore environment in Kirrinjärvi during the summer stagnation period (July). The shallow lake water was oxygen saturated (8 ppm $\mathrm{O}_{2}$; 450 to $500 \mathrm{mV}$ ) down to depths of 2.0 to $2.4 \mathrm{~m}$ and showed $\mathrm{pH}$-values between 6.4 and 6.7 ; the electrical conductivity was about $50 \mu \mathrm{S}$. At greater depths a striking decrease in oxygen content was apparent, which means that the oxygen boundary surface lies at a depth of about $2.4 \mathrm{~m}$. No Fe concentration could be measured in the shallow water $\left(<0.5 \mathrm{ppm} \mathrm{Fe}{ }^{++}\right)$. Because the ore fields in Kirrinjärvi are not deeper than $2 \mathrm{~m}$, the same conditions prevail in the bottom water in these areas.

The lake water at depths between 4.0 and $4.5 \mathrm{~m}$ had only $0.2 \mathrm{ppm}_{2}$ and Eh about 300
$\mathrm{mV}$; the electrical conductivity was about $55 \mu \mathrm{S}$. A low Fe concentration of 2 to $3 \mathrm{ppm}$ was measured in the bottom water.

The concentration of $\mathrm{Fe}$ in the pore water of the surface sediment $(0$ to $12 \mathrm{~cm})$ at depths of $4 \mathrm{~m}$ was between 120 and $200 \mathrm{ppm}$; Ehvalues were 80 to $100 \mathrm{mV}, \mathrm{pH}$ about 6.9 and the electrical conductivity about $120 \mu \mathrm{S}$. Also the pore water of surface sediment samples of shallower lake areas like the nodule fields had $\mathrm{Fe}$ concentrations between 50 and 100 ppm. The measured Mn-content in these pore waters ranges only from 1 to $2 \mathrm{ppm}$.

The water of this dystrophic lake is very poor in electrolytes and hence conductivity is low. But the electrical conductivity indicates connections with the concentrations of dissolved metal ions. The pore waters of the sediments in the ore areas, especially at depths below the oxygen surface boundary, are potentially the most important source of the metal ions required for the formation of freshwater nodules. In the $\mathrm{O}_{2}$-rich environment in the sediment-water interface of the lake ore area the dissolved ions are oxidized and precipitated as less soluble oxides and hydroxides of iron and manganese. The $\mathrm{HCO}_{3}^{-}$-ions are the most important reagent for the aqueous solution of metal ions in the lake sediments. The measured values in the pore water range from 20 to 50 ppm $\mathrm{HCO}_{3}{ }^{-}$.

\section{Chemical and mineral composition}

Chemical analyses of the different lake ore types confirm the classification based on shape (Table 1). The most distinctive feature is the manganese-iron ratio. The crust ores have the greatest content of manganese and a $\mathrm{Mn} / \mathrm{Fe}$-ratio from 0.5 to 0.8 ; the ratios of the penny ores are 0.3 to 0.5 and of the pisolithic ores less than 0.02 . A comparison of these values with the contents of deep-sea 
manganese nodules indicates the higher manganese abundances of the latter and a $\mathrm{Mn} / \mathrm{Fe}-$ ratio from 2 to 3 . The amounts of $\mathrm{Si}, \mathrm{Al}$, $\mathrm{Ca}, \mathrm{Na}, \mathrm{K}$ and $\mathrm{Mg}$ oxides are largely the result of detritus in the freshwater ores.

A very striking difference between the terrestrial concretions and the marine nodules is displayed by the metal contents of $\mathrm{Ni}$ and Co. Whereas the lake ores have only trace contents, the deep-sea nodules possess these metals in such amounts as to make them an important source of metallic raw materials. The main reason for these differences is the diversity of the accumulation rates.

Whereas the lake ores, e.g. in Kirrinjärvi, grew an average of 3 to $4 \mathrm{~mm} / 1000$ years measured by the carbon-isotope-method (Halbach 1972), the growth of marine nodules was markedly slower at rates between 2 and $15 \mathrm{~mm} / 10^{6}$ years (Heye and Beiersdorf 1973). Therefore an active hydrated oxide surface was available for the adsorption of metal ions in the deep-sea environment for a very long time.

The lacustrine sedimentation rates in Finnish lakes range from 80 and $180 \mathrm{~mm} / 10^{3}$ years (Alhonen 1970). In Kirrinjärvi the rate is about $100 \mathrm{~mm} / 10^{3}$ years. In the deep-sea environment manganese nodules are most abundant in areas of slow pelagic sedimentation (Seibold 1973). But even so in both cases the dilemma remains that the nodule accumulation rates are much slower than the rates of lacustrine or marine sedimentation.

Another marked feature of Table 1 is the definite connection between iron and phosphate in the lake ores. With the aid of an electronmicroprobe analysis an almost parallel line-scanning of these two elements was obtained (Halbach 1972). These findings indicate that phosphorus is bound at the ironmatrix, and hence, the pisolithic lake ores have the greatest phosphate content. The behaviour of $\mathrm{Fe}$ and $\mathrm{P}$ is reciprocal to $\mathrm{Mn}$.

By analyzing divalent and tetravalent manganese it is possible to determine the oxidation grade of the samples. The oxidation grade is defined as the proportion of oxygen to manganese.

According to analyses of 4 samples the average oxidation grade was shown to be $1.64 \pm 0.04$ (op. cit.).

Deep-sea manganese nodules have indisputably higher oxygen-manganese-ratios than the latter. These values vary between 1.92 and 1.98 (Price 1967), which means that the lake ores grew in an environment with lower redox-potentials than the deep-sea nodules. Likewise the lower manganese-iron ratios of the lacustrine samples might provide further support for this assumption. With the aid of x-ray analysis a manganese (II)manganate (IV)-phase was identified as the main Mn-mineral in the crust ores; this phase was first reported by Giovanoli et al. (1970) as $\mathrm{Mn}_{7} \mathrm{O}_{12} \cdot 5 \quad \mathrm{H}_{2} \mathrm{O}$, in which the oxidation grade is about 1.7. The main line of this Mn-mineral is at $7 \AA$, which could also be attributed to the mineral birnessite. Furthermore, the lake ores investigated contain $\alpha-\mathrm{FeOOH}$ (goethite), and the pisolithic ores small quantities of $\mathrm{FePO}_{4} \cdot 2 \mathrm{H}_{2} \mathrm{O}$ (strengite). Besides these minerals formed during the ageing of the ore matter, the concretions also exhibit striking portions of amorphous phases. Quartz, feldspar, micas and minute quantities of aktinolite have been identified as the main detrital phases.

\section{Transport of the ions and ore formation}

The lakes can be supplied with iron and manganese by rivers and brooks as well as by ground water. The migration process may have taken place in four possible ways: 


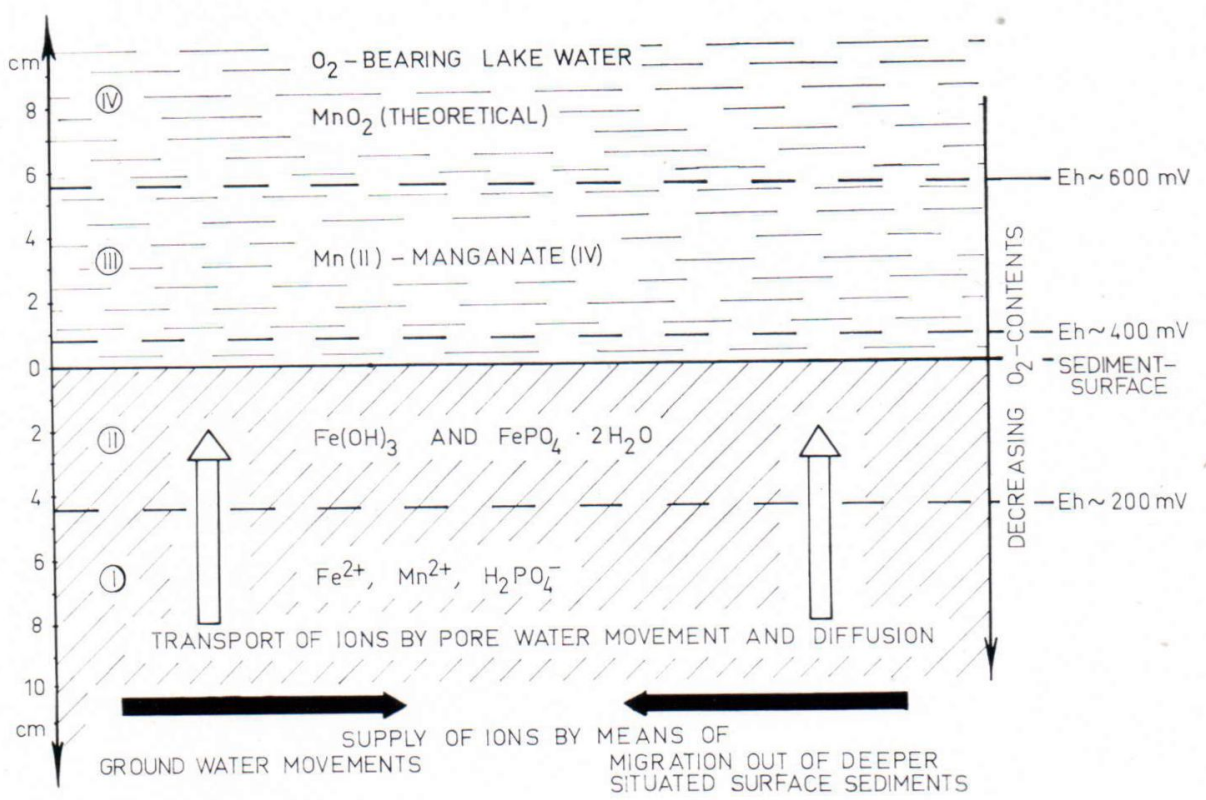

Fig. 6. Theoretical precipitation fields of lake ore phases in relation to Eh.

1. in real ionic solutions,

2. in colloidal pseudo-solutions,

3. bound in organic metal complex compounds, as chelates and humates,

4. bound in solid suspended matter.

For open flowing waters movement in ionic solution at a long range is impossible because of the uptake of oxygen out of the atmosphere; the redox-potentials will increase and cause oxidation and precipitation of the metal ions.

For both elements transport in brooks by colloidal suspensions and in organic complex bond is not impossible. Such transported metals are not flocculated immediately after their entrance into the lake, but they are deposited with the finest particles in the deeper bottom muds. There they are transmitted into ionic solutions owing to the reducing conditions in the pore water, and hence iron and manganese are concentrated in the deeper bottom muds of the lakes.
Another important source may be the ground waters of the swamp areas, which are able to move iron and manganese in ionic solutions. But also such dissolved metals can reach the accumulation area of the lake ores only with the aid of the limnic circulation. The location of the ore formation is not controlled by the direct emergence of ground water.

Figure 6 demonstrates schematically the theoretical precipitation fields of iron-, phosphorus- and manganese-phases in relation to the redox-potentials ( $\mathrm{pH}$ is about 6.7, Halbach 1972).

In zone I all compounds are dissolved. In range II (Eh 200 to $400 \mathrm{mV}$ ) iron phosphate and iron hydroxide are precipitated together as a colloidal mixed phase; this is the favoured area for the formation of pisolithic lake ores. The separation of iron and manganese mainly takes place here by a redox-diffusion process. In the sediment-water interface the 
precipitation of manganese begins and the penny ores with alternating layers of ironand manganese-rich phases are formed by varying redox-potentials.

With the beginning of zone III $(>400 \mathrm{mV})$ there is a marked increase in the precipitation of mixed manganese oxides. Here is the theoretical formation zone of the crust ores.

The limit of zone IV gives the lowest value $(600 \mathrm{mV})$ for the oxidation to tetravalent manganese and thus for the formation of pure manganese dioxide phases. Such high oxidation potentials are possible as maximum values in lake ore fields.

All the accumulation products are initially formed as amorphous colloidal phases, there- fore a mutual influence by autocatalytic effects certainly exists (Jenne 1968). The redox conditions in a lake change with climatic circulation and stagnation periods resulting in a change in position of the reducing zone in the sediment. This change is the reason for the alternating layers of manganese- and iron-rich phases observed in the ore concretions. In these internal structures the fixed results of the changing climatic conditions in the limnic environment of a freshwater lake are visible.

Acknowledgement - The research programme was supported by the "Deutsche Forschungsgemeinschafts.

Table 1. Chemical analyses of ferromanganese concretions ( $\%$ of dry weight).

\begin{tabular}{|c|c|c|c|c|c|c|c|c|c|c|c|c|}
\hline & \multicolumn{9}{|c|}{ Freshwater concretions 1} & \multirow{2}{*}{\multicolumn{3}{|c|}{$\begin{array}{c}\text { Deep-sea manganese } \\
\text { nodules (Pacific) }{ }^{2}\end{array}$}} \\
\hline & \multicolumn{3}{|c|}{ Pisolithic ores } & \multicolumn{3}{|c|}{ Penny ores } & \multicolumn{3}{|c|}{ Crust ores } & & & \\
\hline & aver. & $\max$ & $\min$. & aver. & $\max$. & $\min$. & aver. & $\max$. & $\min$. & aver. & $\max$ & $\min$. \\
\hline $\mathrm{Fe}$ & 43,3 & 45,8 & 41,0 & 13,8 & 19,9 & 8,5 & 26,2 & 28,1 & 24,3 & 6,86 & 11,80 & 3,50 \\
\hline $\mathrm{Mn}$ & 0,5 & 0,8 & 0,1 & 6,8 & 7,4 & 6,0 & 16,3 & 22,6 & 9,3 & 24,07 & 27,25 & 19,08 \\
\hline $\mathrm{SiO}_{2}$ & 9,3 & 15,4 & 4,8 & 40,8 & 49,9 & 29,0 & 14,5 & 22,5 & 6,6 & 13,46 & 18,76 & 11,06 \\
\hline $\mathrm{Al}_{2} \mathrm{O}_{3}$ & 3,3 & 5,9 & 0,4 & 10,3 & 10,9 & 9,4 & 4,3 & 5,1 & 3,2 & 5,53 & 6,83 & 3,78 \\
\hline $\mathrm{CaO}$ & 0,1 & 0,2 & 0,1 & 0,7 & 1,0 & 0,2 & 0,1 & 0,1 & 0,1 & 2,16 & 4,60 & 1,20 \\
\hline $\mathrm{MgO}$ & 0,2 & 0,4 & 0,1 & 1,1 & 1,5 & 0,8 & 0,3 & 0,5 & 0,1 & 2,96 & 5,65 & 1,51 \\
\hline $\mathrm{Na}_{2} \mathrm{O}$ & n.d. & n.d. & n.d. & n.d. & n.d. & n.d. & n.d. & n.d. & n.d. & 1,55 & 1,92 & 0,84 \\
\hline $\mathrm{K}_{2} \mathrm{O}$ & n.d. & n.d. & n.d. & n.d. & n.d. & n.d. & n.d. & n.d. & n.d. & 0,71 & 1,00 & 0,52 \\
\hline $\mathrm{TiO}_{2}$ & $<0,1$ & 0,1 & $<0,1$ & 0,5 & 0,5 & 0,5 & 0,1 & 0,1 & 0,1 & 0,67 & 1,22 & 0,31 \\
\hline $\mathrm{Cu}$ & n.d. & n.d. & n.d. & n.d. & n.d. & n.d. & n.d. & n.d. & n.d. & 0,75 & 1,03 & 0,34 \\
\hline $\mathrm{Ni}$ & aver.: & 0,0072 & & $\max .:$ & 0,0100 & & min.: & 0,00 & & 1,14 & 1,43 & 0,60 \\
\hline $\mathrm{Co}$ & aver.: & 0,0095 & & $\max :$ & 0,0180 & & min.: & $<0,00$ & & 0,20 & 0,30 & 0,12 \\
\hline $\mathrm{Zn}$ & n.d. & n.d. & n.d. & n.d. & n.d. & n.d. & n.d. & n.d. & n.d. & 0,17 & 0,28 & 0,09 \\
\hline $\mathrm{P}_{2} \mathrm{O}_{5}$ & 1,4 & 1,8 & 1,0 & 0,3 & 0,3 & 0,2 & 0,5 & 0,7 & 0,3 & n.d. & n.d. & n.d. \\
\hline $\mathrm{S}$ & $<0,1$ & $<0,1$ & $<0,1$ & $<0,1$ & $<0,1$ & $<0,1$ & $<0,1$ & $<0,1$ & $<0,1$ & n.d. & n.d. & n.d. \\
\hline $\mathrm{CO}_{2}$ & $<0,1$ & 0,1 & $<0,1$ & 0,3 & 0,6 & 0,2 & 0,8 & 0,9 & 0,7 & n.d. & n.d. & n.d. \\
\hline $\mathrm{H}_{2} \mathrm{O}$ b. & 16,5 & 18,2 & 13,4 & 11,4 & 14,8 & 8,8 & 14,6 & 16,0 & 12,9 & n.d. & n.d. & n.d. \\
\hline Org. subst. & . 5,8 & 8,3 & 3,7 & 2,4 & 3,6 & 0,4 & 4,7 & 5,2 & 4,2 & n.d. & n.d. & n.d. \\
\hline
\end{tabular}

1 Samples from lakes in Central Finland

2 Samples of the »Valdivia»-expedition 1972 from the North Pacific (south-east of Hawaii)

\section{REFERENCES}

Aarnio, B. (1915) Über die Ausfällung des Eisenoxyds und der Tonerde in finnländischen Sandund Grusböden. Geotekn. Tied. 16: 1-76.
Alhonen, P. (1970) The palaeolimnology of four lakes in south-western Finland. Ann. Acad. Scient. Fenn., Ser. A III. Geol,-Geogr. 105. 39 p. 
Berner, R. A. (1971) Principles of Chemical Sedimentology. McGraw-Hill Book Company, New York. 240 p.

Borchert, H. (1952) Bildungsbedingungen mariner Eisenerzlagerstätten. Chem. Erde 16: 49-84.

Dubina, G. A. (1970) Untersuchungen über die Morphologie von Metallogenium und die Beziehungen zu Mycoplasma. Allg. Mikrobiol. 10: $309-320$.

Giovanoli, R., E. Stähli and W. Feitknecht (1970) Über die Oxidhydrate des vierwertigen Mangans mit Schichtgitter. Helv. Chim. Acta 53: 453465.

Halbach, P. (1972) Vorkommen, Zusammensetzung und Genese Fe- und Mn-haltiger Erze in Süßwasserseen Finnlands - ein Beitrag zur Geochemie und Entstehung konkretionärer Bodenbildungen. Habilitationsschrift, ClausthalZellerfeld (Techn. Universität). 195 p.

Halbach, P. (1974) Vergleich stofflicher Eigenschaften limnischer und mariner Manganknollen. Erzmetall 27: 161-168.

Heye, D. and H. Beiersdorf (1973) Radioaktive und magnetische Untersuchungen an Manganknollen zur Ermittlung der Wachstumsge- schwindigkeit bzw. zur Altersbestimmung. Z. Geoph. 39: 703-726.

Jenne, E. A. (1968) Controls on $\mathrm{Mn}, \mathrm{Fe}, \mathrm{Co}, \mathrm{Ni}, \mathrm{Cu}$, and $\mathrm{Zn}$ Concentrations in Soils and Water: The Significant Role of Hydrous Mn and Fe Oxides. Adv. Chem. 73: 337-387.

Krauskopf, K. B. (1957) Separation of manganese from iron in sedimentary processes. Geochim. Cosmochim. Acta 12: $61-84$.

Price, N. B. (1967) Some geochemical observations on manganese-iron oxide nodules from different depth environments. Marine Geol. 5: $511-538$.

Seibold, E. (1973) Rezente submarine Metallogenese. Geol. Rdsch. 62: 641-684.

Vaasjoki, O. C. (1956) On the natural occurrence of Manganese in Finland. Pp. 51-52. Symp. d. Manganeso, V. (Europa), XX. Congreso Geolog. Internacional, Mexico.

Vasari, Y., T. Koljonen and K. Laakso (1972) A case of manganese precipitate in the Taviharju esker, Kuusamo, North East Finland. Bull. Geol. Soc. Finland 44: 133-140.

Manuscript received, June 26, 1975. 